\title{
Growth, survival and bone alterations in Piaractus mesopotamicus larvae under different rearing protocols
}

\author{
Crescimento, sobrevivência e alterações ósseas em larvas de Piaractus \\ mesopotamicus em diferentes protocolos de criação
}

\author{
David Roque Hernández ${ }^{I^{*}}$ Carlos Hernán Agüero ${ }^{I}$ Juan José Santinón ${ }^{\mathrm{I}}$ \\ Alfredo Oscar González ${ }^{I}$ Sebastián Sánchez ${ }^{I}$
}

\section{ABSTRACT}

The pacu (Piaractus mesopotamicus) is a neotropical freshwater fish. It is one of the most important species farmed in areas of the Parana and Paraguay Rivers basins. The effects of different rearing protocols on growth, survival and incidence of skeletal malformations in pacu larvae were analyzed. A total of six experimental treatments were considered, consisting of: a semiintensive larviculture $\left(L_{S}\right)$ in ponds; intensive larviculture $\left(L_{I n}\right)$ in laboratory (both $L_{S}$ and $L_{I n}$ until 60 days of life); and mixed larviculture, with 20 days of semi-intensive larviculture into cages in ponds after $14\left(L_{1}\right), 21\left(L_{2}\right), 33\left(L_{3}\right)$ or $40\left(L_{4}\right)$ days of laboratory larviculture. At the end of the experimental period, $L_{S}$ larvae showed higher growth rate, with average weight values (2.28g) and total length (TL-48.20mm) statistically higher than the rest $(P<0.05) . L_{1}$ to $L_{4}$ treatments showed intermediate growth values, without differences between them $(P>0.05)$, while $L$ presented the lowest growth $(P<0.05)$. Survival was around $75 \%$ in all experimental groups, except $L_{S}$, that presented a significantly lower value $(17.5 \%, P<0.05)$. Skeletal abnormalities were detected in all experimental treatments, but $L_{1 n}$ and $L_{1}$ presented the lowest incidence. In no case, visible morphological alterations were found. This study shows that prolonging pacu rearing under laboratory conditions at high densities improves temporal availability and survival of juvenile without affecting growth or subsequent osteological development of fish.

Key words: Piaractus mesopotamicus, larviculture, retention, bone malformations.

\section{RESUMO}

O pacu (Piaractus mesopotamicus) é um peixe neotropical de água doce. É uma das espécies mais importantes cultivadas em áreas de bacias dos rios Paraná e Paraguay. Foi analisado o efeito da duração da larvicultura intensiva no crescimento, sobrevivência e incidência de malformações ósseas em pacu. Os tratamentos consistiram de uma larvicultura semiintensiva $\left(L_{S}\right)$ em viveiros, larvicultura intensiva no laboratório até
60 dias de idade $\left(L_{I n}\right)$, ou misto, com 20 dias de larvicultura semiintensiva após $14\left(L_{1}\right), 21\left(L_{2}\right), 33\left(L_{3}\right)$ e $40\left(L_{1}\right)$ dias de larvicultura no laboratório. No final da experiência, as larvas do tratamento $L_{S}$ apresentaram maior crescimento, com valores de peso médios $(2,28 \mathrm{~g})$ e comprimento total (CT-48,20mm) estatisticamente superior ao resto $(P<0,05)$. Os tratamentos $L_{1}$ a $L_{4}$ apresentaram valores de crescimento intermediários, sem diferença estatística entre eles $(P>0,05)$, enquanto $L_{I n}$ apresentaram os menores valores de crescimento estimados $(P<0,05)$. A sobrevivência foi estimada em torno de $75 \%$ em todos os grupos, com exceção do $L_{s}$ o qual apresentou um valor mais baixo $(17,5 \%, P<0,05)$. Em todos os tratamentos experimentais, foram detectadas alterações esqueléticas, mas em nenhum caso foi encontrado alteração morfológica visivel. O presente estudo mostra que a retenção prolongada de larvas de pacu em alta densidade melhora a disponibilidade temporal e sobrevivência dos juvenis, sem afetar o crescimento ou desenvolvimento osteológico posterior destes.

Palavras-chave: Piaractus mesopotamicus, larvicultura, retenção, malformações ósseas.

\section{INTRODUCTION}

The pacu (Piaractus mesopotamicus) is a neotropical omnivorous freshwater fish. It is one of the most important species farmed in areas of the Parana and Paraguay Rivers basins with great economic importance (CAROLSFELD et al., 2004). This fish is extensively used in aquaculture in Argentina, ranking second in production after trout (Oncorhynchus mykiss) (MINAGRI, 2013). To support the productive development of this species, it is necessary to provide sufficient number of juveniles of high quality. In this sense, the supply of juveniles is considered to be one of the most difficult

\footnotetext{
Instituto de Ictiología del Nordeste, Facultad de Ciencias Veterinarias, Universidad Nacional del Nordeste (UNNE), Sargento Cabral,
} 2139, Corrientes (3400), Argentina. E-mail: dhernandez@vet.unne.edu.ar. "Corresponding author. 
phases of aquaculture (NRC, 1993), and it depends on an optimal larviculture methodology (GARCÍAORTEGA et al., 2001).

The semi-intensive system has been the most frequently method used in Brazil for pacu juvenile production (BOCK \& PADOVANI, 2000). However, in this system low production of juveniles is obtained, making difficult the planning of subsequent culture stages (JOMORI et al., 2003). These authors proposed new technologies to improve reproductive performance of pacu in order to increase the survival rate after rearing larvae for a short period in laboratory conditions before being transferred to external ponds. However, in that study, as well as in other that evaluated growth and survival parameters in pacu larvae under different rearing systems or feeding modes, none of them reported the incidence of bone malformations under these regimes. In this sense, the intensification of production systems should not only consider the increased availability of juvenile but must also be focused on the production of high quality juveniles (GARCÍA-ORTEGA et al., 2001).

Pacu females produce large quantities of viable eggs in a short period of time within the breeding season (DA SILVA et al., 1989), which extends from October to March, coinciding with high water temperature and frequent rainfall (ROMAGOSA et al., 1990; BERNARDINO \& LIMA, 1999). However, when production extends southward, this period is often reduced to a pair of months. This strong reproductive seasonality determines the existence of periods where properlysized juveniles ready for rearing and fattening are not available, becoming one of the main obstacles to regional aquaculture development.

Taking into account the need to expand the supply of juveniles for a longer period of time, this study was conducted in order to determine whether a longer period of permanence on intensive system under laboratory conditions affect the growth, survival and incidence of skeletal malformations in pacu larvae.

\section{MATERIALS AND METHODS}

Location

The experiment was conducted in the experimental aquaculture facilities of the Northeast Institute of Ichthyology (INICNE), Faculty of Veterinary Science-UNNE, Corrientes, Argentina.

\section{Experimental procedures}

Larvae were obtained by controlled reproduction from one couple of $\boldsymbol{P}$. mesopotamicus from the INICNE (Corrientes, Argentina). Spawning was artificially induced by injection of pituitary extract of Prochilodus lineatus, according to DA SILVA et al. (1988). After hatching, larvae were kept in a 5001 tank with flow-through water $\left(25^{\circ} \mathrm{C}\right)$ and forced aeration during four days until complete absorption of the yolk sac and beginning of exogenous feeding. At that time, 18 batches of 2000 larvae were randomly placed into six experimental groups (three replicates per treatment), which consisted of: semiintensive larviculture $\left(\mathrm{L}_{\mathrm{S}}\right)$ in extern ponds; intensive larviculture $\left(\mathrm{L}_{\mathrm{In}}\right)$ in laboratory conditions (both $\mathrm{L}_{\mathrm{S}}$ and $\mathrm{L}_{\mathrm{In}}$ until 60 days of life); or initial intensive larviculture until $14\left(\mathrm{~L}_{1}\right), 21\left(\mathrm{~L}_{2}\right), 33\left(\mathrm{~L}_{3}\right)$ or $40\left(\mathrm{~L}_{4}\right)$ days of life before being transferred to extern ponds in cages. Fish from $\mathrm{L}_{1}, \mathrm{~L}_{2}, \mathrm{~L}_{3}$ and $\mathrm{L}_{4}$ experimental groups were reared in suspended cages for 20 days after the transference moment (Figure 1).

In $\mathrm{L}_{\mathrm{S}}$, larvae were placed in three extern ponds $\left(16 \mathrm{~m}^{2}\right)$ at a density of 125 larvae $\mathrm{m}^{-2}$. Ponds were fertilized with $300 \mathrm{~g} \mathrm{~m}^{-2}$ of dry alfalfa (Medicago sativa) for plankton production one week before larvae transference. In laboratory, batches of larvae were placed in fifteen aquaria (100L capacity) at a density of 20 larvae $\mathrm{L}^{-1}$, three of which were maintained until 60 days of life $\left(\mathrm{L}_{\text {In }}\right)$. The remaining twelve batches were transferred to extern ponds at set times for $\mathrm{L}_{1}$ to $\mathrm{L}_{4}$ treatments (see Figure 1). For each transference moment, three batches of 125 larvae were placed in 1 $\mathrm{m}^{3}$ suspended cages in extern ponds for 20 days, at the same stocking density as used in $\mathrm{L}_{\mathrm{s}}$. The experience lasted 60 days to $\mathrm{L}_{\mathrm{S}}, \mathrm{L}_{\mathrm{In}}$ and $\mathrm{L}_{4}$, being Artemia nauplii the only food supply offered in laboratory, while dry diet $(32 \%$ crude protein and $411 \mathrm{kcal}$ of crude energy $100 \mathrm{~g}^{-1}$ ) was used to complement the natural food in ponds and cages. All groups were daily fed ad libitum at 8:00, 11:00, 14:00, 17:00 and 20:00h, throughout the experimental period. The water temperature and dissolved oxygen averages in extern ponds were $30.7 \pm 1.28^{\circ} \mathrm{C}$ and $10.8 \pm 1.25 \mathrm{mg} \mathrm{L}^{-1}$, respectively, while in laboratory conditions were $28.5 \pm 0.35^{\circ} \mathrm{C}$ and $6.5 \pm 0.85 \mathrm{mg} \mathrm{L}^{-1}$, respectively.

\section{Registration data}

Growth parameters were obtained by sampling 90 fish per treatment (30 per replicate) as follow: i) all groups at the start (4 dah) of the experimental period: ii) for $\mathrm{L}_{\mathrm{S}}$ and $\mathrm{L}_{\mathrm{In}}$ treatments after 14, 21, 33, 40 and 60 dah; iii) and for $L_{1}$ to $L_{4}$ treatments, when transferring batches from laboratory to the cages and after 20 days of cage culture in ponds.

Weight (W), total length (TL), specific growth coefficient (SGC) and survival rate (S) were calculated as follows: $\mathrm{W}(\mathrm{g})=\mathrm{W}_{t} N^{-1}$, where $\mathrm{W}_{t}$ is the total weight $(\mathrm{g})$ of the sample and $N=$ number 


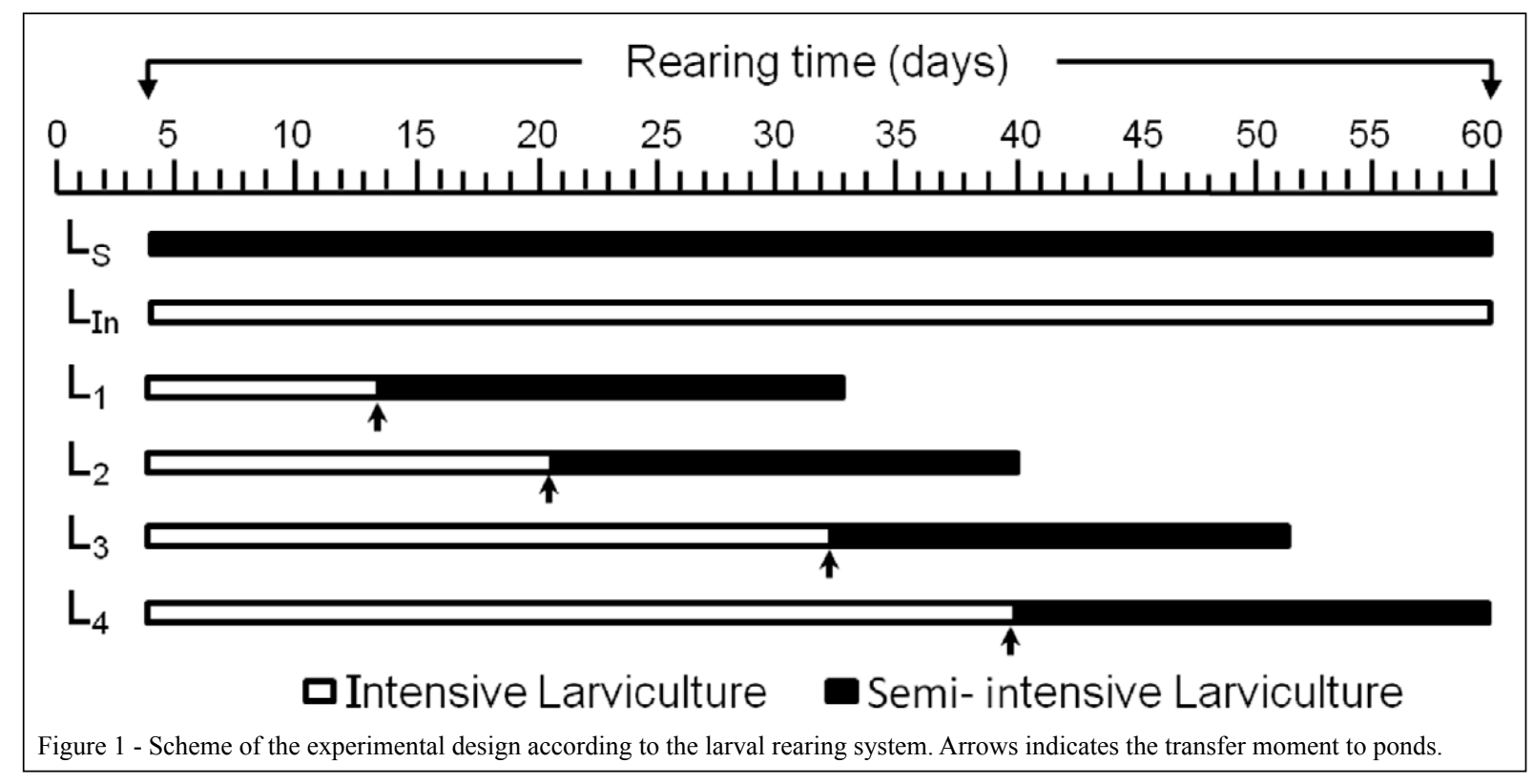

of animals; TL $(\mathrm{mm})=\Sigma \mathrm{TL}_{i} N^{-1}$, where $\Sigma \mathrm{TL}_{i}$ is the summation of the total length $(\mathrm{mm})$ of the sampled fishes and $N=$ number of animals; SGC $=[100(3(W$ $\left.\left.\left.{ }^{0.33}-W_{i}^{0.33}\right)(\mathrm{T})^{-1}\right)\right]$, where $W_{f}=$ final mean weight, $W_{i}=$ initial mean weight expressed in grams of a specific period $(\mathrm{T})$ and 0.33 correspond to the allometric growth coefficient estimated for fish (HEPHER, 1988); S (\%) $=100\left(N_{f} N_{i}^{-l}\right)$, where $N_{f}$ and $N_{i}=$ final and initial number of fish, respectively.

\section{Skeletal anomalies}

Thirty larvae per treatment (ten per replicate) were transparentized and stained using a modification of the TAYLOR \& VAN DYKE (1985) technique for bone disorders observation. Specimens were stained with Alcian blue $8 \mathrm{GX}(0.02 \%$ in $70 \%$ alcohol and 30\% glacial acetic acid) and macerated using a 3\% aqueous solution of $\mathrm{KOH}$ (potassium hydroxide) until skeletal elements were clearly visible. Then were stained with Alizarin red S (stock solution: $1 \%$ Alizarin red in $1 \% \mathrm{KOH}$ ). Staining time was variable depending on the size of the specimen. At the end, specimens were preserved in pure glycerin. Images were obtained using a Kyowa optical binocular microscope equipped with a Sony SDZ digital camera. Anomalies incidence were evaluated over the vertebral axis (compression and fusion) and the caudal skeleton (deformed, absent, fused or supernumerary)according toBOGLIONEetal.(2001).

Statistical analysis

The results of the experiment were analyzed using one-way analysis of variance
(ANOVA), according to a completely randomized design with six treatments and three replications $(\mathrm{n}=18)$. Duncan's multiple range test was used as a post hoc test to compare differences between means at $\mathrm{P}<0.05$. The software used for data analysis was Statistica for Windows, version 6.0.

\section{RESULTS}

After 60 days of rearing, $\mathrm{L}_{\mathrm{S}}$ larvae presented highest growth parameters with average weight of $2.28 \pm 1.30 \mathrm{~g}$, differing statistically from $\mathrm{L}_{\text {In }}$ $(0.22 \pm 0.06 \mathrm{~g})$ and $\mathrm{L}_{4}(0.43 \pm 0.10 \mathrm{~g})(\mathrm{P}<0.05)$. The $\mathrm{L}_{1}$ to $\mathrm{L}_{4}$ treatments presented final weights ranging between $0.42 \pm 0.17$ and $0.65 \pm 0.21 \mathrm{~g}$, without significant differences between treatments $(\mathrm{P}>0.05)$ (Figure 2A). The analysis of SGC, considering the total duration of the rearing period to each group (60 days in $\mathrm{L}_{\mathrm{s}}, \mathrm{L}_{\text {In }}$ and $\mathrm{L}_{4}, 34$ in $\mathrm{L}_{1}, 41$ in $\mathrm{L}_{2}$ and 53 in $\mathrm{L}_{3}$, respectively) showed significant differences between most of them $(\mathrm{P}<0.05)$ (Figure 2B). However, when analyzing the $\mathrm{SGC}$ in $\mathrm{L}_{1}$ to $\mathrm{L}_{4}$ treatments, considering only 20 days of semi-intensive culture in cages, there was no difference between treatments $(\mathrm{P}>0.05)$ (Figure 2C).

Survival rate in $\mathrm{L}_{\mathrm{S}}$ treatment was significantly lower $(17.5 \%)$ than the estimated for the other treatments $(\mathrm{P}<0.05)$. The survival rate during the intensive larviculture was around $75 \%$. Larvae that received an initial intensive larviculture, presented high survival rate after 20 days of cage culture in ponds, with values above $90 \%$.

The number of vertebrae most commonly observed was 39 (4 corresponding to the Weber

Ciência Rural, v.45, n.9, set, 2015. 
(A)

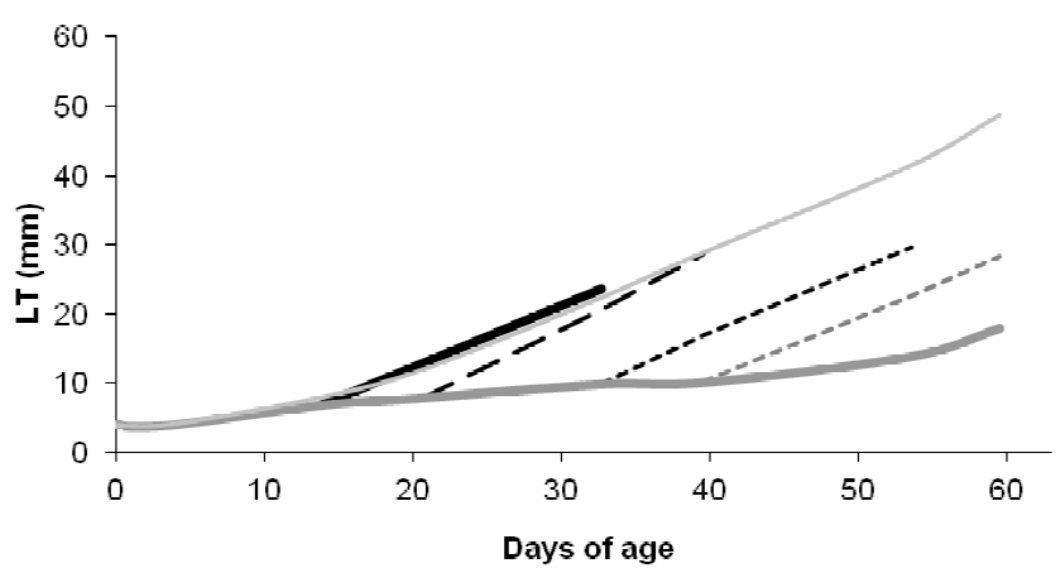

$\longrightarrow \mathrm{L} 1--\mathrm{L} 2----\mathrm{L} 3----\mathrm{L} 4 \longrightarrow \mathrm{LIn} \longrightarrow \mathrm{LS}$

(B)

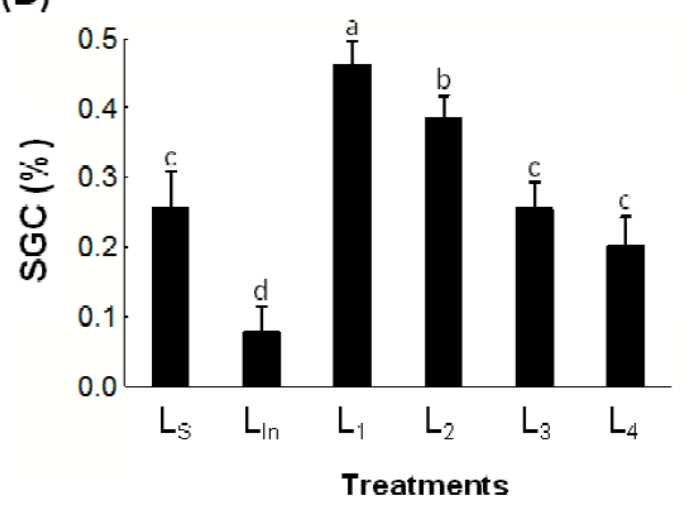

(C)

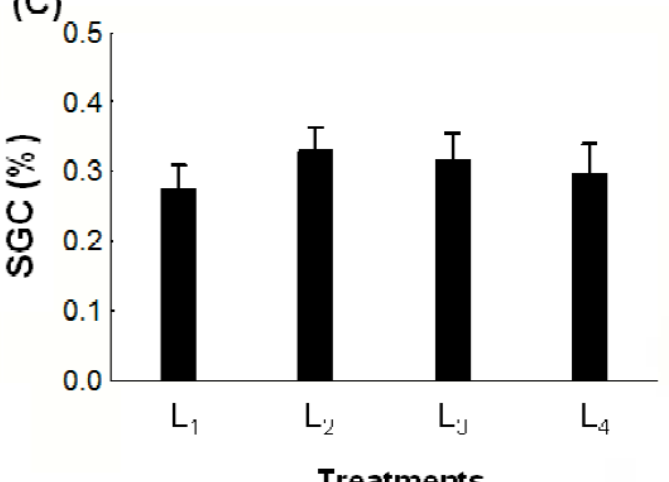

(D)
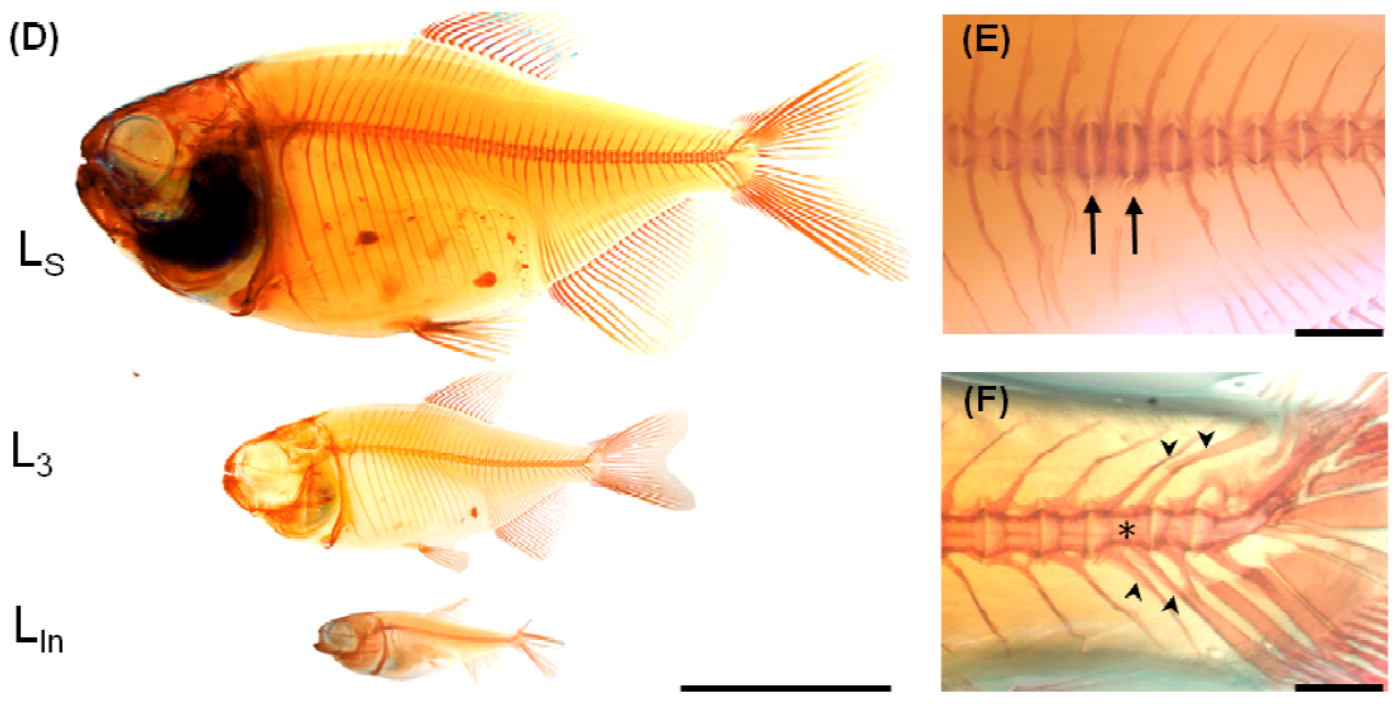

Figure 2 - Growth and skeletal development of pacu larvae reared under semi-intensive, intensive or mixed larviculture systems. (A) Growth parameters (TL) at the end of each period, (B) specific growth coefficient including total culture, (C) specific growth coefficient in ponds after different periods of intensive larviculture. Different letters indicate statistical differences between treatments $(\mathrm{P}<0.05)$. (D) vertebral column with normal development under semi-intensive system $\left(\mathrm{L}_{\mathrm{S}}\right)$, intensive larviculture for 60 days $\left(\mathrm{L}_{\mathrm{In}}\right)$ or 33 days in laboratory plus 20 days reared in cages $\left(\mathrm{L}_{3}\right)$. (E and $\left.\mathrm{F}\right)$, different kinds of bone malformations, the arrow $(\uparrow)$ indicates compressions, arrowhead ( ) hemal and neural duplicated spines and asterisk (*) vertebral fusion. Bars, $\mathrm{D}=20 \mathrm{~mm}, \mathrm{E}$ and $\mathrm{F}=1 \mathrm{~mm}$. 
apparatus, 16 to the precaudal and 19 to the caudal vertebrae, including the last ones the vertebrae of the caudal skeleton). Fish from $\mathrm{L}_{\mathrm{s}}$ treatment presented a variation of 39-40 in vertebrae number, while for the other groups a variation of 38-39 vertebrae was observed. In both cases variations occurred only in the caudal region, and no significant differences were observed $(\mathrm{P}>0.05)$. In all experimental groups, different types of skeletal abnormalities were observed (vertebral fusions and compressions, bifid or duplicated neural and hemal spines and caudal skeleton deformities). These anomalies were more frequently found on the spine that in caudal skeleton, affecting 39.2 and $28.9 \%$ of evaluated fish, respectively. However, no significant differences between experimental groups were found $(\mathrm{P}>0.05)$.

In $\mathrm{L}_{\mathrm{S}}$ treatment, vertebral compression was the most frequent bone alteration observed (Figure 2E), whereas in treatments which were subject to intensive larviculture for a certain period, alterations consisted mainly of bifid or duplicated neural and hemal spines (Figure 2F). In no case evident morphological alterations were observed (Figure 2D).

\section{DISCUSSION}

In the present study, highest weights were attained by fish placed directly in ponds at low density, when comparing with those maintained in laboratory. Similar results were reported by FONTES \& SENHORINI (1994) in pacu larvae reared at low density under semi-intensive systems. According to JOMORI et al. (2003), such results could be directly related to stocking density and the abundance of natural food in ponds; when fish density is low, the availability of live food increases.

The low growth observed in $\mathrm{L}_{\text {In }}$ is in agreement with that reported by PINTO \& CASTAGNOLLI (1984). These authors observed that pacu larvae reared in laboratory at the same density as used in the current study, showed low growth within 30 days of life. However, although $\mathrm{L}_{\text {In }}$ showed the lowest growing rate during the experimental period, it was observed that after a short period of rearing in ponds at low density ( $\mathrm{L}_{1}$ to $\mathrm{L}_{4}$ treatments), fish rapidly increased in size, reaching levels similar to those observed in pacu reared for 30 days in semi-intensive systems (FONTES \& SENHORINI, 1994). This result could be indicating that growth potential was not affected by extending the laboratory culture period, pointing to a compensatory growth mechanism, such as reported in pacu (SOUZA et al., 2000).

In intensive systems, larvae are reared at high densities in small tanks under controlled conditions (PAPANDROULAKIS et al., 2004). Under this system, large numbers of juveniles are obtained with few broodstock. However, mortality is also high due to the lack of adaptation when transferring fishes from laboratory conditions to external ponds (BOCK \& PADOVANI, 2000). In contrast, extensive larviculture systems employ low stocking densities in large areas with natural food production, obtaining moderate to low survival rates (CHABALIN et al., 1989), demanding many broodstock and a great quantity of available ponds to supply the commercial demand of juveniles at industrial level. This study found that maintaining pacu larvae under laboratory conditions improves subsequent survival of fish after being reared in ponds when compared to direct larviculture in ponds. Similar results were reported by JOMORI et al. (2003) noting that in pacu larvae, initial intensive larviculture is very efficient and the longer the time kept under this system, the higher the survival rate obtained in ponds.

Factors such as feeding, rearing systems and fish genetics are known to produce osteological alterations and variability in the meristic features in fish (LALL \& LEWIS-MCCREA, 2007; CASTRO et al., 2008; ROO et al., 2010). Different species of larvae reared under intensive larviculture system usually present higher rate of bone malformations (ROO et al., 2010), when compared with extensive or semi-intensive systems (KOUMOUNDOUROS et al., 2001). Recently, LOPES et al. (2014) reported a range of 39-41 vertebrae in pacu larvae obtained from six wild breeding couples and reared for 30 days under laboratory conditions. In this study it was observed a smaller range (38-40), and in fish reared under laboratory conditions $\left(\mathrm{L}_{\mathrm{in}}, \mathrm{L}_{1}, \mathrm{~L}_{2}, \mathrm{~L}_{3}\right.$ and $\left.\mathrm{L}_{4}\right)$ it was observed the absence of one vertebra (38-39) when compared to those reared in Ls (39-40). ZOUITEN et al. (2011) reported that in Dicentrarchus labrax larvae reared in a semi-intensive system the absence of one vertebra was more frequently observed when comparing with those reared at high densities. HERNÁNDEZ et al. (2013) reported variations in the number of vertebrae in Rhamdia quelen larvae from different biotypes reared under laboratory conditions. Also, VILLENUEVE et al. (2006) observed a high incidence of supernumerary vertebrae in D. labrax larvae fed with excess of fatty acids in the diet. The high variability in meristic features found in farmed fish can be attributed to the interaction between genetic and environmental factors (BOGLIONE et al., 2001; KOUMOUNDOUROS et al., 2001, HERNÁNDEZ et al., 2013).

In this study, the low rate of skeletal alterations observed on vertebral centrum in larvae 
reared for an extended period under laboratory conditions could be related to the slow growth of fish under this system, which in turn, could favor harmonious development of different organs and systems (KOUMOUNDOUROS et al., 1999). This is in agreement with the results of LOPES et al. (2014) who reported absence of skeletal abnormalities on the vertebral axis in pacu larvae after 30 days of rearing under laboratory conditions. In contrast, the incidence of skeletal abnormalities observed on vertebral centrum in $\mathrm{L}_{\mathrm{S}}$ could be associated to a possible deficiency or imbalance of some nutrients in the feeding of specimens that have high growing potential under these systems. ZOUITEN et al. (2011) observed that D. labrax larvae reared under a semi-intensive system presented faster ossification patterns when compared to the same species reared under an intensive larviculture system. According to these authors, the osteological development process was affected when a rapid allometric growth exists, resulting in an asynchrony between muscular system and skeletal structures development.

JOMORI et al. (2003) observed that the best moment for transferring pacu larvae from the laboratory into ponds is between 11 and 14 days of life. In the present study, pacu larvae reared under laboratory conditions for more than 30 days showed satisfactory growth potential and their subsequent morphological development was not affected. The results provide support for making use of the high fertility of pacu in order to extend juvenile supply by transferring batches of larvae to ponds for a few days according to the commercial demand. In conclusion, maintenance of pacu larvae under controlled condition improves the seasonal availability of high quality juveniles, as well as the survival parameters of fish.

\section{ETHICS AND BIOSAFETY COMMITTEE}

The procedures adopted with the animals in this research were in accordance with the ethical principles of animal experimentation, and approved according to protocol n. 0019/ 14-2011-02204 and 14-2012-03865 by the Ethics and Biosafety Committee of School of Veterinary Sciences of the Northeast National University (UNNE) of Argentine.

\section{REFERENCES}

BERNARDINO, G.; LIMA, V.A. Situação da criação de Colossoma e Piaractus no sudeste do Brasil (1988-1991). In: SOUZA, R.H.S. Criação de Colossoma e Piaractus no Brasil. IBAMA (Ed), Brasília. 1999, p.173-232.

BOCK, C.L.; PADOVANI, C.R. Considerações sobre a reprodução artificial e alevinagem de pacu (Piaractus mesopotamicus, Holmberg, 1887) em viveiros. Acta Scientiarum, v.22, p.495-
501, 2000. Available from: <http://periodicos.uem.br/ojs/index. php/ActaSciBiolSci/article/view/2935/2120>. Accessed: apr. 23, 2013. doi: $10.4025 /$ actascibiolsci.v22i0.2935

BOGLIONE, C. et al. Skeletal descriptors and quality assessment in larvae and post-larvae of wild-caught and hatcheryreared gilthead sea bream (Sparus aurata L. 1758). Aquaculture, v.192, p.1-22, 2001. Available from: <http://www.sciencedirect. com/science/article/pii/S0044848600004464>. Accessed: mar. 16, 2011. doi: 10.1016/S0044-8486(00)00446-4.

CAROLSFELD, J. et al. Migratory fishes of South America: biology, fisheries, and conservation status. Washington D.C and Ottawa: World Fisheries Trust/ Word Bank/ IDRC, 2004. 372p.

CASTRO, J. et al. Heritability of skeleton abnormalities (lordosis, lack of operculum) in gilthead seabream (Sparus aurata) supported by microsatellite family data. Aquaculture, v.279, p.18-22, 2008. Available from: $<$ http://www.sciencedirect.com/science/article/pii/ S0044848608002998>. Accessed: dec. 12, 2008. doi: 10.1016/j. aquaculture.2008.04.023.

CHABALIN, E. et al. Estimativa de custo de produção de larvas e alevinos. Boletim Técnico do CEPTA, v.2, p.61-74, 1989. Available from: $\quad<$ http://www.icmbio.gov.br/cepta/images/stories/producao cientifica/estimativa_1989_01.pd $>$. Accessed: apr. 27, 2013.

DA SILVA, A.B. et al. Manual de reproducción de peces Colossoma (pacú y tambaqui), Tarapoto. San Martín (Perú): In: Juárez-Palacios, J.R. (Ed.) Avances en el Cultivo de Peces del Genero Colossoma. FAO, Roma, 1989. 245p. Available from: $<$ http://www.fao.org/3/contents/391d6836-ae01-530a-9df5941c5eadbe94/AB491S00.htm\#TOC>. Accessed: may 11, 2013.

FONTES, N.A.; SENHORINI, J.A. Larvicultura do pacu Piaractus mesopotamicus Holmberg, 1887, (Teleostei Serrasalminae) em diferentes densidades de estocagem. Boletim Técnico do CEPTA, v.7, p.49-58, 1994. Available from: <http:/www.icmbio.gov.br/ cepta/images/stories/producao_cientifica/lavircultura_1994_01. pdf>. Accessed: apr. 27, 2013.

GARCÍA-ORTEGA, A. et al. Evaluation of protein quality in microbound started diets made with decapsulated cysts of Artemia and fish meal for fish larvae. Journal of the World Aquaculture Society, v.32,p.317-329,2001.Available from:<http://onlinelibrary. wiley.com/doi/10.1111/j.1749-7345.2001.tb00455.x/abstract>. Accessed: may 8, 2013. doi: 10.1111/j.1749-7345.2001.tb00455.x

HEPHER, B. Nutrición de peces comerciales en estanques. Dor, Israel: Fish and Aquaculture Research Station, 1988. 311p.

HERNÁNDEZ, D.R. et al. Crecimiento, supervivencia e incidencia de malformaciones óseas en distintos biotipos de Rhamdia quelen durante la larvicultura. Latin American Journal of Aquatic Research, v.41, p.877-887, 2013. Available from: $<$ http://www.scielo.cl/scielo.php?script=sci_arttext\&pid=S0718560X2013000500008\&lng=es>. Accessed: nov. 14, 2013. doi: 103856/vol41-issue5-fulltext-8.

JOMORI, R.K. et al. Growth and survival of pacu Piaractus mesopotamicus (Holmberg, 1887) juveniles reared in ponds or at different initial larviculture periods indoors. Aquaculture, v.221, p.277-287, 2003. Available from: <http://www.sciencedirect.com/ science/article/pii/S0044848603000693>. Accessed: apr. 23, 2013. doi: 10.1016/S0044-8486(03)00069-3. 
KOUMOUNDOUROS, G. et al. Ontogeny and allometric plasticity of Dentex dentex (Osteichthyes: Sparidae) in rearing conditions. Marine Biology, v.135, p.561-572, 1999. Available from: <http:// link.springer.com/article/10.1007/s002270050657\#>. Accessed: may 08, 2013. doi: 10.1007/s002270050657.

KOUMOUNDOUROS, G. et al. The effect of rearing conditions on development of saddleback syndrome and caudal fin deformities in Dentex dentex (L.). Aquaculture, v.200, p.285-304, 2001. Available from: <http://www.sciencedirect.com/science/article/ pii/S004484860100552X>. Accessed: may 08, 2013. doi: 10.1016/ S0044-8486(01)00552-X.

LALL, S.P.; LEWIS-MCCREA, L. Role of nutrients in skeletal metabolism and pathology in fish, an overview. Aquaculture, v.267, p.3-19, 2007. Available from: <http://www.sciencedirect. com/science/article/pii/S004484860700227X>. Accessed: jan. 15, 2010. doi: 10.1016/j.aquaculture.2007.02.053.

LOPES, T. et al. Skeletal anomalies of pacu, Piaractus mesopotamicus, larvae from a wild-caught broodstock. Journal of the World Aquaculture Society, v.45, p.15-27, 2014. Available from: $<$ http://onlinelibrary.wiley.com/doi/10.1111/jwas.12092/abstract $>$. Accessed: apr. 4, 2014. doi: 10.1111/jwas. 12092.

MINAGRI. Boletín de la Dirección de Acuicultura. Dirección Nacional de Planificación Pesquera Subsecretaria de Pesca y Acuicultura de la Nación. Buenos Aires (Argentina), p.1-19; 2013. Available from: <http://www.minagri.gob.ar/site/pesca/ acuicultura/index.php>. Accessed: apr. 27, 2013.

NATIONAL RESEARCH COUNCIL(NRC). Nutrient requirements of fish. Washington, DC: National Academy, 1993. 114p.

PAPANDROULAKIS, N. et al. Mesocosm: a reliable technology for larval rearing of Diplodus puntazzo and Diplodus sargus sargus. Aquaculture International, v.12, p.345-355, 2004. Available from: <http://link.springer.com/article/10.1023\%2FB\% 3AAQUI.0000042134.21211.ab>. Accessed: apr. 22, 2013. doi: 10.1023/B:AQUI.0000042134.21211.ab.

PINTO, M.L.; CASTAGNOLLI, N. Desenvolvimento inicial do pacu Colossoma mitrei (Berg, 1895). III SIMPOSIO
BRASILEIRO DE AQUICUltURA, Sao Carlos, SP. Anais... São Carlos: Brasil, 1984. p.523-535.

ROMAGOSA, E. et al. Pattern of oocyte diameter frequency distribution in females of the pacu Piaractus mesopotamicus (Holmberg, 1887) = Colossoma mitrei (Berg, 1895), induced to spawn. Aquaculture, v.86, p.105-110, 1990. Available from: $<\mathrm{http} / /$ www.sciencedirect.com/ science/article/pii/004484869090225C > . Accessed: apr. 11, 2013. doi: 10.1016/0044-8486(90)90225-C.

ROO, J. et al. Effect of rearing techniques on skeletal deformities and osteological development in red porgy Pagrus pagrus (Linnaeus, 1758) larvae. Journal of Applied Ichthyology, v.26, p.372-376, 2010. Available from: $<$ http://onlinelibrary.wiley.com/ doi/10.1111/j.1439-0426.2010.01437.x/pdf >. Accessed: apr. 3, 2013. doi: $10.1111 /$ j. 1439-0426.2010.01437.x.

SOUZA, V.L. et al. Effects of food restriction and refeeding on energy stores and growth of pacu, Piaractus mesopotamicus (Characidae). Journal of Aquaculture in the Tropics, v.15, p.371-379, 2000. Available from: <http://www.cabdirect.org/ abstracts/20013012452.html>. Accessed: may 10, 2012.

TAYLOR, W.R.; VAN DYKE, G.C. Revised procedure for staining and clearing small fishes and other vertebrates for bone and cartilage study. Cybium, v.2, p.107-119, 1985.

VILLENUEVE, L. et al. Intake of high levels of levels of vitamin A and polyunsaturated fatty acids during different developmental periods modifies the expression of morphogenesis genes in European sea bass (Dicentrarchus labrax). British Journal of Nutrition, v.95, p.677-687, 2006. Available from: <http://journals. cambridge.org/action/displayAbstract? fromPage $=$ online $\&$ aid $=923$ 412\&fulltextType $=$ RA\&fileId $=$ S0007114506000894 $>$. Accessed: dec. 10, 2012. doi: 10.1079/BJN20051668.

ZOUITEN, D. et al. Comparison of growth, digestive system maturation and skeletal development in sea bass larvae reared in an intensive or a mesocosm system. Aquaculture Research, v.42, p.1723-1736, 2011. Available from: <http://onlinelibrary.wiley. com/doi/10.1111/j.1365-2109.2010.02773.x/abstract $>$. Accessed: apr. 20, 2013. doi: 10.1111/j.1365-2109.2010.02773.x. 